\title{
Challenges of Expanding Internally Generated Revenue in Local Government Council Areas in Nigeria
}

\author{
Maurice Ayodele Coker ${ }^{1,3}$, Felix Onen Eteng ${ }^{1,2}$, Tabitha Venenge Agishi ${ }^{3} \&$ Hilary Idiege Adie ${ }^{1,2}$ \\ ${ }^{1}$ Department of Political Science, University of Calabar, Calabar, Nigeria \\ ${ }^{2}$ Department of Public Administration, University of Calabar, Calabar, Nigeria \\ ${ }^{3}$ Department of Political Science, Benue State University, Makurdi - Benue State, Nigeria \\ Correspondence: Maurice Ayodele Coker, Department of Political Science, University of Calabar, Calabar, \\ Nigeria. E-mail: coker_maurice@yahoo.com
}

Received: June 11, 2015 Accepted: June 16, 2015 Online Published: November 23, 2015

doi:10.5539/jsd.v8n9p79 URL: http://dx.doi.org/10.5539/jsd.v8n9p79

\begin{abstract}
Availability of adequate financial resources are desirous for any organization to achieve the purposes for which it is established. Local government councils in Nigeria are created statutorily to perform clearly assigned functions. Experience has however demonstrated that these councils have fallen short of achieving the objectives for which they were indorsed. Some reasons have been espoused by scholars for the failing performances of most local government councils in Nigeria. Against this backdrop, this study seeks to posit that local government councils are likely to achieve their set objectives to a large extent if their internally generated revenue (IGR) are expanded. Also, the study seeks to postulate the capacity of local government councils in Nigeria to sustainably expand their internally generated revenue (IGR) is inhibited by the kind of strategies adopted and by some critical challenges facing them. To enable the explication of the assumption, the study adopts a conscious survey of relevant literature on our subject matter. The data generated are systematically analyzed to verify the validity of the above assumptions. The study maintains that apart from the fact that the fiscal federalism apparently seem unfavourable to the local government functional responsivities, it has nevertheless the provided for adequate source for their internally generated revenue to augment the federally allocated funds. Again, sundry factors hinders the expansion internally generate revenue have been identified and recommendations for boosting IGR in local government councils in Nigeria have also been articulated.
\end{abstract}

Keywords: Internally generated revenue, local government councils, financial resources, fiscal federalism, strategies

\section{Introduction}

The major challenge confronting most local government councils in developing countries such as Nigeria is that of having a firm financial base to enable them pay for charges incurred for their respective administrative activities. Experience has shown that the expected financial bases local government councils have tended to become very unauthentic, given the straitened sources of internally generated revenue to complement the federally allocated source. It is not unusual in Nigeria that most local government councils in the country cannot generate sufficient funds internally for their developmental needs. In fact, the central problem has tended to be that of not sufficiently identifying, and adopting appropriate strategies for expanding their revenue bases internally. Achieving this objective would substantially assist in augmenting the apparently grossly inadequate external sources of funding. The issue of the narrow revenue base within the local government system in Nigeria is a matter of serious concern for both policy makers and implementers; because it adversely affects the performance of local government councils' statutory responsibilities as a veritable agent of rapid rural development and transformation. The paper argues as follows: that local government councils in Nigeria have ample sources of generating revenue internally; these sources must be clearly delineated and areas of responsibilities and accountabilities made; what is generated deposited in government treasury; problem of endemic corruption and other related vices tackled robustly; and, dependence on the federal government for "hand-outs" drastically reduced. The other area of critically is the flourishing financial and resource emasculation of local governments by their respective States governments. 


\section{Statement of Problem}

It is an incontrovertible fact that "the extent to which a local government can go in accomplishing its goal will largely depend on its internally generated revenue" Olusola $(2011 ; 2014)$. The problem however, is that most local government councils in Nigeria lacks the capacity or political will to raise corollary funds to it's statutorily allocated from the states and federal governments as required by fiscal federalism which she operates. In fact, Fiscal federalism entails a clearly demarcated functions as enshrined in the legislative lists of the Federal Republic of Nigeria. According to Kizito and Fadila:

In a federal system such as Nigeria, there exist three tiers of government namely federal, state and local governments. The constitution provides for the functions of the different tiers of government.... Consequently, resources are allocated to the three tiers of government from the federation account to enable them carry out their functions effectively in addition to the revenue generated internally by each tier of government (2015: 2).

From the above it become very clear that both the states and local governments are expected to depend mainly two main streams of resource funding: from the federation account and internally generated revenue. This implies that part of the resource needed the both the states and local governments are to be realized by putting in place robust machinery that would enable the generation the requisite funds to augment their federally allocated finances. In the local government councils the problem of achieving this goal has tended to be an uphill task. This is due to the fact that much of the internally generated revenue are either grossly embezzled or misappropriated by most political office holders. The bureaucrats at all levels are not left in actuating corruption and other related vices; which have largely contributed to the paucity of funds in the local government councils. Correspondingly, Kizito and Fadila (2015) have reiterated the fact that state/local joint account has tended to become a "vehicle for deducting, diverting and misapplying the allocating to local government councils, and this has continue to drastically reduce the funds of local governments...."

In line with the above, local governments in Nigeria are by no means independent. They tend to be dependent on both the central and state's governments for their financial sustainability. Nwatu (1995) notes that it is unfortunate that local government councils in the Nigeria's $21^{\text {st }}$ century are still dependent upon the state and federal allocations, and grants for their operations and sustenance. The question therefore is, why is that local governments despite their varied sources of internally generated revenue, (which are classified under the following: Head 1001 - Taxes; Head 1002 - Rates; Head 1003 - Local licenses, fines and fees; Head 1004 Earnings form commercial undertakings; Head 1005 - Rent on local government property; Head 1006 - Interest, payment and dividends; Head 1007 - Grants; and, Head 1008 - Miscellaneous... (Ola and Tonwe, 2003); are financially incapacitated, to the extent that they depend solely on the federal government for funds to pay monthly emoluments of their workers. What role then has IGR in contributing to public finance at the local government level? The primary sources of IGR according to Ola and Tonwe, 2003; Olusola, 2011; 2014) constitutes "the live wire of a local government ... because it is the only source that the local government has control over". Furthermore, Olusola (2011) defined IGR as "the revenue that local government generates within the areas of its jurisdiction". Olusola (2011) and Ola and Tonwe (2015) are agreed that extent to which a local government may achieve the realization of their developmental goals "will be largely depended upon their IGR strength".

Arising from the above, it becomes very clear that the Olusola and Siyanbola (2014) notes that "capacity of a local government to generate revenue internally is one very critical consideration for the creation of a local government council". Generating revenue internally is an important statutory function of a local government. One of the raison d'tre for creating a local government is the belief that it could create and sustain rapid socioeconomic and political development (with internally generated funds which complements the states and federally allocated finances) at the grassroots level. Generating revenue internally local councils in Nigeria is spike by financially unhealthy practices which tends to go on with impunity for a very long time. Consequently, it is the position of this study that transparent, responsible and accountable strategies should be reinvented to assist effective revenue regeneration and mobilization. Such revenues must end up in government treasuries, rather than in private and incorrigibly corrupt political and bureaucratic leaders' pockets.

\section{Literature Review and Theoretical Framework}

The imperative for mobilizing and utilizing the desired revenue for local government transformation cannot be 
overemphasized. However, studies have shown that "one of the major macroeconomic challenges facing low income countries is inadequacy of financial resources to provide the needed infrastructural facilities" (Kizito \& Fadila, 2015). Contradictively, assessing requisite funds would enhance the greater level of autonomy for them as well as guarantee the requisite finances necessary for that purpose. Correspondingly, the local government councils would exhort some level of non-interference in its statutory functions and responsibility from both the state and central governments. Olusola (2011) see internally generated revenue (IGR) as the "revenue that local government generates within the area of its jurisdiction".

Therefore, Ojong (2000) advances the position that if the local government councils can ably generate their internal revenue adequately, they would deliver appropriate services and development programmes more effectively to the people with a view to synergising rapid socioeconomic development of the rural dwellers. In fact, Ugwu (2000) argues that the merit of internal sources of revenue is that it strengthens local government's autonomy because if local government can satisfactorily generate a large proportion to its revenue internally, it would cease reliance on the state and federal government statutory allocations. This according to him would in turn enhance the creditability of local government as they would be able to fulfil their duties and obligations to their immediate communities. Hence, Ugwu concludes that harnessing the internally generated revenue will assist the local government meet their needs. This implies to effectively harness revenue internally and taking into cognizance that achieving that goal is replete with debilitating problems, appropriate strategies to enhance the base of IGR in local government councils must be formulated and implemented.

\subsection{Functions of Local Government Councils}

In Nigeria, the functions of local government councils are explicitly enshrined in the 1999 Constitution of the Federal Republic. The Fourth Schedule of the Constitution provides as follows the functions of local government councils:

1) Formulation of economic planning and development of areas of authority and be actively involved in the economy planning of the state.

2) Provide Health Services to the people through the effective establishment and running of health centres and organization of immunization programmes to eradicate some dreaded diseases noticed in their localities.

3) Establishment and maintenance of cemeteries, burial grounds and home for destitute and disabled persons

4) Assist in the implementation of National development programmes that will enhance massive food production in their localities.

5) Embark on infrastructural development such as construction of roads, streets, drainages, motor parks and recreational centres in their localities.

6) Collect taxes and rates for the running of their councils, subject to the taxes approved by State House of Assembly.

7) Make Bye-Laws that will enhance peace and tranquillity in their localities or domains (cited in Abgani \& Ugwoke, 2013: 148).

It is not unexpected that local government councils in Nigeria is perceived as a veritable instrument for diffusing socioeconomic and political development of Nigeria. This is partially anchored on the realization that vast majority of the citizenry resides in local areas. Again, local council's area are where the food and even the oil come from. Hence, it makes a lot of sense to devolve the above stated functions to the local government areas. However, it is imperative to observe realizing these functions require commensurate funding of which the Constitution has also taken care in the fiscal policy of the Federal Republic of Nigeria. This is discussed in what follows.

\subsection{Fiscal Federalism and Local Government Councils Sources of Revenue}

Nigeria operates a federal system of government in which duties and functional responsibilities are largely delineated and sources for funding public administration shared among the three tiers. The three tiers: local, state, and federal government are assumed to be independent yet coordinated in their spheres of functional and financial authority. Specifically, in Nigeria, Olaniyi (1999) posts that "fiscal federalism is the arrangement through which responsibilities and functions are shared among the constituted levels of government". Olaniyi (1999) pointed out that this arrangement is predicated on two factors; namely: spatial character of public service and scale economics. The first factor is concerned with "the geographical spill over effects or benefits from (localized) collective action," while the second one ensures that "people share the benefits from services the national government is best suited to provide". 
Correspondingly, fiscal federalism ensures that the allocation of revenue is "done through the sharing of tax jurisdiction and /or redistribution of federally collectable revenue among the three tiers of government". (Olaniyi, 1999). The share of the revenue distributed is largely dependent upon their "relative functions and between units in the same tiers of government". Over the years, a number of revenue allocation commissions has been raised to ensure acceptable formula for sharing distributable revenue form the federation account to the three tiers of government. Among these commissions are the Phillipson Commission (1946), Hick-Phillipson Commission (1951), Chicks Commission (1953), Raisman Commission (1958), Binns Commission (1964), and Dina Commission (1969). Iniodu (1999) notes that these Commissions were saddled with the responsibility of allocating revenue to only the federal and regional, and later states governments. Later, in the 1979's and 1980, the Aboyade Committee (1977) and the Okigbo Commission (1980) initiated the process whereby the local government were officially incorporated into the formal sharing formula as a tier of government. According to Iniodu (1999) the Vertical formula for distribution funds to the three tiers of government, (as recommended by the Committee) was: Federal Government - 57.0 per cent; State Governments - 30.0 per cent; Local Governments - 10.0 per cent; and, Special Grants - 3.0 per cent. It was also recommended that each state government should contribute over 10.0 per cent of its internally generated revenue to the local governments. The Horizontal formula recommended: equality of, and access to, development opportunities ( 25 per cent); national minimum standard for national integration ( 22 per cent); absorptive capacity ( 20 per cent), independent revenue and minimum tax (18 per cent) and fiscal efficiency ( 15 per cent). The above recommendation was rejected for being too technical as it would difficult to implement (Iniodu, 1999). This paved the way for the Okigbo Commission (1980). The Okigbo Commission recommended for horizontal revenue allocation as follows: minimum responsibility of government (40 per cent), population (40 per cent), social development (15 per cent), and internal revenue effort (15 per cent). That notwithstanding, in 1993, Mbanefoe (Iniodu, 1999) recommended the following formula for vertical distribution of revenue: Federal government - 53.0 per cent; State Governments - 30.0 per cent; and, Special Funds - 7.0 per cent. The formula was accepted with modification in the 1981 Revenue Allocation inter-alia: Federal Government - 55.0 per cent; State Government - 30.5 per cent; Local Government - 10.0 per cent, and Special Funds -4.5 per cent. To translate from years of ad hoc revenue sharing committees to a more permanent arrangement, in 1989 the National Revenue Mobilization, Allocation and Fiscal Commission (NRMAFC) by Decree No. 49 of 1989. It is noteworthy that in 1997 and 1998 the share of revenue accruing to the Local Governments was upgraded to 25 per cent and 30 per cent respectively. The local governments were to benefit from the Value Added Tax (VAT) which was to replace the Sales tax.

\subsection{Internal Revenue of Local Government}

As noted earlier, apart from the statutorily monthly allocations to local government from both the Federal and States Governments, Local Government are required to generate substantial revenue from internal sources. In fact, Local government councils in Nigeria are expected to generate their internal revenues from the following taxes and levies.

Table 1. Showing taxes and levies to be collected by local governments

\begin{tabular}{ll}
\hline 1 & Shops and Kiosks rates \\
\hline 2 & Tenement rates \\
3 & On and Off liquor license fees \\
4 & Slaughter slab fees \\
5 & Marriage, birth and birth and death registration fees \\
6 & Naming of street registration fee, excluding any street in the state capital. \\
7 & Right of occupancy fees on lands in rural areas, excluding those collectable by the federal and state \\
& governments \\
8 & Market taxes and levies, excluding any market where state finance is involved \\
9 & Motor parks levies \\
10 & Domestic animal license fees \\
11 & Bicycle, truck, canoe, wheelbarrow and cart fees, other than a mechanically propelled truck \\
12 & Cattle tax payable by cattle farmers only
\end{tabular}


13 Merriment and road closure levy

14 Radio and television license fees (other than radio and television transmitter)

15 Vehicle radio license fees (to be imposed by local government of the state in which the car is registered)

16 Wrong parking charges

17 Public convenience, sewage and refuse disposal fees

18 Customary burial ground permit fees

19 Religious places establishment permit fees

20 Signboard and advertisement permit fees

Source: Taxes and levies (Approved List for Collection) Decree 1998, No. 21 p. 303; cited by Iniodu, P.U. Fiscal dependence of local governments in Nigeria's fiscal system: the case of Akwa Ibom State. In: Fiscal Federalism and Nigeria's Economic Development. The Economic Society. Selected Papers Presented at the 1999 Annual Conference.

It is not an understatement to argue that the above mentioned sources of revenue constitutes a veritable, and realistic revenue generation and mobilization gadget for rural transformation in Nigeria if properly harnessed and accounted for. It is a truism that given the dependency mentality of most Nigerians, sourcing of needful revenue should come the "Oil Revenue". Local government have largely tended to overlook other genuine sources of revenue as they await their monthly statutorily allocations. Even where efforts are made to generate them internally, a large portion of it are embezzled by either public office holders, contractors, bureaucrats or the enforcement offices. A number of encumbrances are encountered by Local Governments in their attempt to raise adequate matching funds to assist the development of their respective domain as provided for in the constitution. In what follow attempt is made to identify first: the strategies for expanding internally generated revenue; and, second, the factors which hinders the process.

\section{Methodology}

This study focuses on first examining the nature of internally generated revenue in local governments in Nigeria taking into considering the fact that IGR have tended to contribute very abysmally to the revenue bases of local government councils in the country. The study attempts to provide answers to the following question among others:

1) Are the constitutionally assigned sources of IGR to LGAs inadequate?

2) Are the LGAs" inability to source adequately for IGR due to their overbearing dependence on the statutory allocations from the Federation Account or other reasons such as the crippling corruption and other related offences in the country?

3 ) It is due to their inability to expand their IGR frontiers?

To achieve the purpose of study, the researchers depended on exploring mainly available data generated from extant literature, specifically, reliance on surveys of secondary sources. The data generated is consequently systematized into headings and sub-headings to order the understanding of our subject-matter. An analysis of the data assembled is subject to critical appraisal with a view to linking the interconnected of the relations among our variables of study. Thereafter, conclusion and recommendations are made.

\section{Factors hindering expansion of Internally Generated Revenue in Local Government Councils in Nigeria}

Many factors may be advanced as problems militating against expanding internally generated revenue by local government councils in Nigeria. These factors are as follows:

\subsection{Corruption, Fraud and Misappropriation of Generated Revenue}

There is a high incidence of corruption, fraud and embezzlement among local government revenue officials. Some of these unscrupulous council's officers collect revenue for which they issue fake receipts to the payers, and the funds collected are not paid into the councils' treasuries. Others collect revenue without issuing receipts. It is by so doing that large sums of revenues are lost by local governments to some corrupt and fraudulent rates and fee's collectors, licensing officials, collectors of fees and fines, market masters, and valuation officers. Furthermore, some tenement assessments are under evaluated, or they completely escape valuation and rating. At particular points, it is very common for local government enforcement officers ensure that the poor are the payer of the tenement rates, whereas the rich and the well-connected escape payment. Awotokun (1995) identified 
corruption and fraud as major problems of local government in Nigeria. For example, he observed that the Kaduna South Local Government Council suspended 20 Revenue Collectors for diversion of large sums of the Council's internally generated revenue. This was reported by then local government Caretaker Committee Chairman, Alhaji Suleiman Aliyu. Aliyu (1995) opines that this kind of fraudulent practice is prevalent in most local government councils throughout the country. Indeed, Atakpa et al (2012), citing Newswatch Magazine edition of December 20, 1993, captioned "Fortress of Corruption: Audit Report indicts Local Government of Fraud and Corruption,"' corroborated that "most local governments in Nigeria today have become centres or fortresses of corruption." The Report highlighted that "all the Chairmen of the twenty-one local governments in a particular state were pronounced guilty of financial irresponsibility; that the local government councils had become fortresses of financial malpractices...." These fraudulent and corrupt practices have tended to deprive the local government of their legitimate finances.

\subsection{The Prevalence of Poverty}

A substantial number of rural and urban dwellers are indigent. They are not only indigent but remain redundant in most cases. The poor and unemployed are endowed with the capacity to contribute to internally generated revenue in their localities, since they lack the wherewithal to pay the demanded rates or taxes. This problem becomes heightened in a situation where, for example, demands for tenement rate's payment are contracted out to an agency/contractor who turns around to make tenement rate demands that by far outpaced the actual revenue for the house owner, or the cost to the building. Under such circumstances, the probable revenue will dwindle due to the inability of the house owners to pay the projects. Consequently, the probable internal revenue source would not yield expected revenue layout. This is due to an absence of reasonable tenements worthy of valuation and rating. Nzelibe (1990) observed that most of these local government markets and motor parks are not fully developed to yield expected revenue. That is, most of the internal revenue sources assigned to the local government councils are either undeveloped or absent in some of the council areas. This may be as a result of neglects of such revenue sources by the local government council areas. For instance, due to dependence of local governments in the state and federal government for financial sustenance, television and bicycles, fees are hardly considered as sources of their revenues. Again due to the imposition of very high tenement rate on private buildings, and the noncompliance by house owners, the revenue derivable there from is extremely minimal.

\subsection{Lack of Qualified and Experienced Revenue Officers}

The finance and audits' departments of many local governments in Cross River State are not sufficiently staffed with well trained, qualified and experienced financial managers, accountants, clerks, auditors and property valuation officer who would apply their skills and initiatives to develop pragmatic plans and strategies to enable them harness and exploit fully and effectively the internal revenue sources. Atakpa et al., (2012) posits that some local government officials "exhibit their inability to keep proper and adequate accounting records" because they" have little or no knowledge about the accounting systems in local government." These problems are further compounded by poor assessment methods. This implies that most of the local government councils in Nigeria may not have well trained planning and budgeting officers necessary for efficient financial plans in the areas of internally generated revenue sourcing.

\subsection{Nigerian Revenue Sharing Formula Is Skewed against the Local Government Financial Sustainability}

A cursory observation of the revenue allocation formula in Nigeria had tended to reflect what Olatunbosun (1975) called "benign neglect." This neglect of financially empowering local government council are clearly manifested in their share of federally allocated revenue over the years. The increasing reduction of the scope of fiscal responsibility to local governments constitutionally, despite the dynamic scale of their functional responsibilities has tended to further incapacitate the ability of local government to perform.

\subsection{Lack of Foresight and Entrepreneurial Skills on the Part of Key Local Government Functionaries and the Revenue Officials Militate against Effective Generation of Revenue Locally}

Local government functionaries are supposed not only to effectively mobilize requisite revenue, but also to explore, identify and exploit potential sources of revenues in the areas of jurisdiction. However, this expectation has tended to be misplaced due to their lack of foresight and entrepreneurial skills. In most rural communities, high illiteracy rate, poor sanitary condition, and dearth of basic social, educational, and other infrastructural facilities. The local inhabitants lack the sophisticated exposure to strategically improve the revenue base of their respective localities.

5.6 The success or failure of any local government in Nigeria largely depends not only on availability of financial resources but effective utilization of these resources. Local government funds should be spent or 
productive and socially rewarding ventures.

5.7 Inability to implement bye-laws. Adewumi (1994) argues that "the major problems of internal revenue generation in the local government centre on the inability of local governments to enforce bye-laws, which could enhance their revenue collection.

\section{Strategies for expanding LGR in Local Government Councils}

It is pertinent at this juncture to examine what LGAs may do in order to expand their revenue bases in Nigeria. These include:

1. All sources of collectable fines and taxes must be identified, and appropriate instruments and procedures fashioned out to achieve their effective collection and mobilization. Table 1. Presented elsewhere in this paper clearly shows the statutorily assigned items for which local governments have fiscal legislative rights.

2. State-Local Government Joint Account should be abrogated due to the following reasons:

i. The Local Government Councils stand to enhance their revenue base since all statutorily allocated revenue will be remitted to their account directly from the Federation Account; without any deductions by the States government.

ii. Local government Councils apart from managing and controlling their funds would be a position to invest in areas in which the local has comparative advantages, especially in agricultural ventures.

iii. State Governments have tended act as drain-pipe of finances from local government council area by taking over some of the sources of local government revenue; for example, from markets, motor parks, etc.

3. Local governments should invest in revenue yielding business and commercial concerns. This if properly managed will enhance their revenue base. Establishing cottage industries and primary processing of solid minerals; where available in abundance through local initiative will reduce the level of unemployment and poverty in the area.

4. It is of grave concern that one of the avenues of depriving local government councils of improved revenue base is the fact most of the local government staff do not reside in their local government of work. To make the matter worse the majority of political office holders do not also reside in their respective local council. In fact very few of them invest in those locality, not to talk of building house for which tenement rates could be realized. They are absentee "agent of development". Little wonder then that all these years their positive impact is not adequately felt financially in their local government areas.

5. Revenue generation officers should be meritoriously recruited, trained and monitored in day-to- day performance of their duties. To perform effective training Workshop, Conferences should be periodically organized for Revenue officers. In such educative gatherings the capacity of the revenue officers are improved. Proper ethically orientation is also inculcated in them.

6. All sources of financial leakages should be blocked. It is a common practice for enforcement officers to issue fake receipt for genuine payment; under remit to public treasury what has been receipted for; and outright abscond with public monies with impunity.

7. All abandoned sources of revenue should be resuscitated; these include: Radio, Television, Wheelbarrow, Sanitation, and affordable tenement rates, among others. These sources of local revenue if consciously assessed and implement will tremendously boost IGR in Local government councils

8. All forms of clientelism or political patronages in outsourcing generation of revenue activities should be discouraged; and staff of local governments should made to perform their official duties.

9. All revenue generate must be paid into government treasury in accordance with extant Civil Service Rules and Financial Regulations.

10. E-accounting should be introduced and proper Staff Audit taken periodically.

11. All levies and taxes should be assessed on the basis of the generally acceptable bases: equity, affordability and reasonable; if the levies and taxes are raised far beyond the reach of the people, there is the tendency that less revenue will be realised as fewer people would pay. However, where it is affordable more people will pay thereby realizing substantial revenue.

12. In fact, Coker and Adams (2012) note that local government finance can expand and be properly managed if the following debilitating issues are comprehensively addressed; inter-alia: 
i) Lack of the requisite and desirable financial autonomy necessary for effective management of their financial resources.

ii) Lack of qualified staff to management the books of the local governments

iii) Some officials of the councils collaborate with those who are supposed to keep their watch to loot the local government treasuries.

iv) Local government accounts are not appropriately kept, as monies meant for the local authorities/treasuries are not properly accounted for.

v) Laying of local government budgets before the States' Governors and Houses of Assembly members gives room for horse trading and pigeon-holding of projects based on locality interests and community's needs.

vi) Corruption has taken the central stage in most local governments, hence, most internally generated revenue are not paid into local governments accounts. These are clearly demonstrated in lack of transparency and accountability; Viewing Council's funds as "fruits" for party allegiance and loyalty or extensions of private funds; and, embezzlement and falsification with impunity or reckless abandonment of Councils Account Books and other related financial Documents. The attitude of the citizens towards corruption and other related vices must change; hence, "the government should orientate the people to perceive corruption, not as way of our life, but as something that must be abhorred" (Coker et al., 2012).

\section{Summary and Conclusion}

The study has reviewed the various sources of revenue to local government councils in Nigeria. These comprises the statutory allocations from the States and Central governments. The other source is the internally generated revenue. Local governments councils in Nigeria have tended to depend on the statutorily allocated finances from the Federation Account. Hence, it can safely be said that payments for all administrative charges, of in fact all the levels of governments in the country are largely drawn from their monthly statutory allocations. Consequently, IGRs are therefore diverted into private pockets in what appears like primitive accumulation of capital (Obo, et al., 2014), thereby depriving the LGAs of their expected revenue. The primitive accumulation of capital by both politicians and bureaucrats in the LGAs results in the development of underdevelopment of the rural sectors. Indeed, the devastating outcomes of this primitive accumulation of capital is graphically captured in the following words:

[T] he Nigerian state (Local Governments) is controlled by a very greedy and rapacious ruling class whose essence is self-aggrandisement, and to the members of this class, the welfare of the citizenry means very little or nothing (Obo, et al. 2014:67).

Furthermore, Obo, et al. laments

Nigeria is a country of paradoxes: it makes billions of dollars annually form only one resource (i.e., crude oil) yet millions of its people are wretched. In fact, over seventy per cent of its population is said to be enmeshed in extreme poverty (2014:71).

The dependence and extreme poverty wrought primitive accumulation of local government by the ruling class is definitely one avenue of decreasing the level of internally generated revenue in LGAs, and in effect depriving the much needed resource to effective their rapid socioeconomic development.

This is contrary to the major policy thrust upon which the creation of this tier of government is hinged. Really, it was expected that, the internally generated revenue would augment the funds transferred from both the state and federal government to the local government councils. The contrary seem pervasively to be case. A number of reasons has been advanced elsewhere in this paper for this situation. The position of the authors is that if the problems identified and strategies for expanding internally generated revenue in local government are strictly defined within each local context and vigorously pursued, enormous amount of revenue will be harnessed from each of them.

\section{References}

Abgani, B. J., \& Ugwoke, R. O. (2014). The State Joint Local Government Accounting System Challenges on Rural Development in Nigeria. Research Journal of Finance \& Accounting, 5(18). 
Adebayo, A., \& Rowland, L. (1974). Local Government Finance in Nigeria. Journal of African Affairs, 73(290), $112-114$

Adesoji, A. A. (2013). The Effect of Internal Revenue Generation on Infrastructural Development. A Study of Lagos State Internal Revenue Service. Journal of Educational and Social Research, 3(2).

Adewumi, J. B. (1994). Essential feature of the Revised Financial Memoranda for the local government. A commissioned background paper for National orientation Workshop on the use of the Revised Financial Memoranda for senior local government functionaries organized by the Ministry of State and Local Government Affairs, Abuja, from Sept. $22^{\text {nd }}-23^{\text {rd }}$ October, p.1.

Akioye, S. (2013). Federal Allocation....The Nightmare is not over. The Nation Newspaper, Monday October14, 2013.). In B. J. Abgani, \& R. O. Ugwoke (2014). The State Joint Local Government Accounting System Challenges on Rural Development in Nigeria. Research Journal of Finance \& Accounting, 5(18). Retrieved April 7, 2015, from http://www.iiste.org/Journals/index.php/RJFA/article/download/16219/16602

Atakpa, M., Ocheni, S., \& Nwankwo, B. C. (2012). Analysis of options for Maximizing Local Government Internally Generated Revenue in Nigeria. International Journal of Learning and Development, 2(5). http://dx.doi.org/10.5296/ijld.v2i5.2345

Coker, M. A., \& Adams, J. A. (2012). Challenges of Managing Local Government Finance in Nigeria. Research on Humanities and Social Sciences, 3(3). Retrieved January 4, 2013, from http://iiste.org/journals/index.php/RHSS.article/article/view/1608

Coker, M. A., Ugwu, D., \& Adams, J. A. (2012). Corruption and Direct Foreign Investments in Nigeria: Challenges of Implementing Anti-Corruption Programmes under Obasanjo, 1999-2007. Global Advanced Research Journal of History, Political Science \& International Relations, 1(4), 79-88.

Constitution of the Federal Republic of Nigeria. (1999). Government Printing Press, Abuja

Cross River State Local Government Edict No. 18, 1976:133-114.

Egonmwan, J. A. (1984). Reinvesting Local Government in Nigeria. SMO Aka and Bros Press. Benin City, Nigeria.

Hofer, C., \& Schendel, D. (1978). Strategy Formulation: Analytical Concepts. St Paul West Publishing Company, $\mathrm{MN}$.

Iniodu, P. U. (1999). Fiscal Dependence of Local Governments in Nigeria's Fiscal System: The Case of Akwa Ibom state. In: Fiscal Federalism and Nigeria's Economic Development. The Economic Society. Selected Papers Presented at the 1999 Annual Conference.

Kizito, E. U., \& Fadila, J. (2015). The Challenges of State and Local Government Joint Account and its impact on Rural Development in Nigeria. Retrieved March 7, 2015, from http://www.academia.edu/7977731/P_a_g_e_The_Challenges_of_State_and_Local_Government_Joint_Acc ount_and_its_impact_on_Rural_Development_in_Nigeria

Njoku, D. (1998). Introduction to Local Government Administration. Owerri Creative Consultants.

Nwatu, D. N. (1995). Local Government in Nigeria: An Introduction. Agathe Service Publishers Ltd, Enugu.

Nzelibe, C. G. O. (1991) Current Issues in Public and Local Government Administration. Fourth Dimension Publishers. Enugu.

Obo, U. B., Coker, M. A., \& Omenka, J. I. (2014). The State as an Instrument of Primitive Accumulation: The Nigerian Example, 1999-2013. Journal of law, Policy and Globalization, 26.

Ogunna, A. E. (1996). A Handbook on Local Government in Nigeria. Owerri. Versatile Publishers.

Ojong, M. O. (2002) Introduction to Local Government Administration in Nigeria (1st ed.). SSAJJU Inst. Press. 52 Abitu Avenue, Calabar.

Ola, R. O. F., \& Tonwe, D. A. (2003). Local Administration and Local Government in Nigeria. Lagos, Mixon Publishers.

Oladimeji, A. D., \& Monisola, A. E. (2013). Strategic Control and Revenue Generation: A Critical Success Factor in Local Government Administration Using the Balanced Scorecard. International journal of Innovative Research \& Development, 2(10).

Olusola, O. O. (2011). Boosting Internally Generated of Local Governments in Ogun State, Nigeria (A Study of 
selected Local Governments in Ogun State. European Journal of Humanities and Social Sciences, 8(1) (Special Issue).

Olusola, O. O. (2014). The Role of Internally Generated Revenue in Local Government Administration in Nigeria. Journal of Management \& Social Sciences Research (JBM\&SSR), 3(5).

Ugwoke, R. O. (2005). Public Sector Accounting. Enugu. Kinsman Publishers Ltd.

Ugwu, S. C. (2000). Issues in Local Government and Urban Administration in Nigeria, Echrist and company, Enugu Nigeria.

\section{Copyrights}

Copyright for this article is retained by the author(s), with first publication rights granted to the journal.

This is an open-access article distributed under the terms and conditions of the Creative Commons Attribution license (http://creativecommons.org/licenses/by/3.0/). 